\title{
The Research on the Key Success Factors of Mobile Internet with Interpretative Structural Modelling*
}

\author{
Jiangping Wan ${ }^{1,2}$, Yahui Zhu ${ }^{1}$, Lianyu Liang ${ }^{1}$ \\ ${ }^{1}$ School of Business Administration, South China University of Technology, Guangzhou, China; ${ }^{2}$ Institute of Emerging Industrializa- \\ tion Development South China University of Technology, Guangzhou, China. \\ Email: csjpwan@scut.edu.cn, zhuyahui0819@qq.com,jade_go@163.com
}

Received August $3^{\text {rd }}, 2013$; revised August 25 ${ }^{\text {th }}, 2013$; accepted August $31^{\text {st }}, 2013$

Copyright @ 2013 Jiangping Wan et al. This is an open access article distributed under the Creative Commons Attribution License, which permits unrestricted use, distribution, and reproduction in any medium, provided the original work is properly cited.

\begin{abstract}
Today mobile Internet is a rapidly rising area. How to deal with the disruptive transition? This paper is intended to study the success factors of mobile Internet with grounded theory and it is the result that 17 success factors are identified. Then the following top 10 key success factors are found out through the questionnaire: the user traffic and scale, product and service innovation, keen market environmental sense, the user experience and business model innovation, core technology, the development of mobile terminals, e-commerce and online payment services, customized services and applications of cloud computing and big data. Finally, interpretative structural modeling (ISM) is applied to analyze the relationship among the key success factors and the root key success factors of mobile Internet were figured out, as they are product and service innovation, keen grasp of market environment, the user experience and core technology. The results will be enlightened for the enterprises of mobile Internet, mobile phone manufacturers and operators.
\end{abstract}

Keywords: Mobile Internet; Key Success Factors; Grounded Theory; Interpretative Structural Modeling (ISM)

\section{Introduction}

As an emerging market, there is no stable development model of mobile Internet. However, it is necessary for the mobile Internet to find out its key success factors to continue the healthy development, which relates to its success or failure. The characteristics of the mobile Internet include: quickly technological change, short product life-cycle, fast improvement of product performance and technology etc., which make the analysis and evaluation of the mobile Internet difficult to be quantified. In order to solve this problem, interpretative structural modeling (ISM) is used in this paper.

This paper is organized as follows: introduction and literature review are in the first, and then the research design followed. After identifying the influence factors of mobile Internet with Grounded Theory, the hierarchical structural relationship among the key success factors (KSF) is analyzed with ISM, to find out the root success factors and their influence relation.

\footnotetext{
*This research was supported by Key Project of Guangdong Province Education Office (06JDXM63002), NSF of China (70471091), and QualiPSo (IST-FP6-IP-034763).
}

\section{Literature Review}

Mary Meeker, titled the "queen of the Internet", the executives of Kleiner Perkins venture-capital firm, said in a speech at Stanford University recently that the global mobile Internet traffic was growing so fast that it even exceeded the Internet traffic of desktop system in some areas. Besides, the mobile industry was still in the early development stage with great potential [1]. The huge market prospect of mobile Internet attracts the telecom operators, terminal manufacturers, Internet companies, systems integrators etc., leading to the flourish [2].

Kate Matsudaira said: You want to make sure that APIs return quickly and do not block while waiting for results, since mobile clients have a limited number of connections, and design your APIs to allow clients to request just the information they need [3]. Nafaa Jabeur, Sherali Zeadaly, Biju Sayed argued that 1) Along with PC functions, TV, games, and business services are available through mobile devices, wherever and whenever a user might want them. 2) Mobile devices are readily discoverable by nearby people and social services. 3) Even more services are expected soon, along with nu- 
merous challenges and questions about privacy and data security [4].

Nicholas C. Zakas argued that the best way to combat latency is to use as few HTTP requests as possible for a website or application. The overhead of creating a new request on a high-latency connection is quite high, so the fewer requests made to the Internet, the faster a page will load [5]. Iris Junglas and Jeanne Harris argued that 1) The usage of consumer devices and applications in the workplace is a global phenomenon, however, it is by no means a uniform one. Employees in Brazil, China, India, and Mexico show disproportionally higher consumer IT utilization rates in the workplace than any other markets studied. 2) Employees in emerging markets believe that using consumer tools for work boosts their empowerment and, with it, their innovative nature-more so than employees in mature markets. 3) More employees in emerging markets experience consumer IT as a productivity enhancer, making them more efficient and effective at work [6].

The main steps of grounded theory are as follows [7]: 1) Theoretical sampling; 2) Collecting information; 3) Coding information, and forming the concepts from information; 4) Continually comparing between data, and between conceptions and between data and conceptions; 5) Forming theoretical conceptions, and establishing the relationships between conceptions; 6) Building theory and judging it.

ISM is based on the qualitative analysis, belongs to the structure model and it can translate the fuzzy thought and views into an intuitive model with good structure. ISM work program can be divided into the following steps: 1) implement the ISM group, including technical experts, coordinators and participants; 2) set the key issues; 3) select the factors have influence on the key issues of the system; 4) list the correlation of the factors; 5) establish the adjacency matrix and accessible matrix, according to the correlation; 6) breakdown the accessible matrix and build the structure model; 7) establish the interpretative structure model based on the structure model [8].

\section{Research Design}

Firstly, Grounded Theory is used to identify the factors contributing to the success of mobile Internet, after reading the relevant literature and reports about mobile Internet in the recent years. Secondly, the hierarchical structure relation among the key success factors of mobile Internet is analyzed with ISM. And finally, the key success factors and their relationship can be found out. Other methods involved in the study include: 1) Depth interview. Using Grounded Theory, interview the entrepreneurs and experts in the field of mobile Internet with in-deep situation, to confirm influence factors. 2) Questionnaire. Design the questionnaire with the possible in- fluence factors and conduct the surveys with the senior practitioners in mobile Internet industry, and conesquently the key success factors are acquired by statistical analysis (Figure 1).

\section{The Identification of the Influence Factors of Mobile Internet with Grounded Theory}

The influence factors to the success of mobile Internet were identified with Grounded Theory. Taking depth interviews, we understood the development status of mobile Internet and found out the influence factors.

The five experts selected have the following characteristics: 1) well educated, be able to accept and understand new things quickly, and can express clearly; 2) work in mobile Internet industry for more than 5 years, and be familiar with the development of the Internet industry; 3) have a certain understanding of the related technologies which mobile Internet need.

Through the continued comparison with the raw data and the concepts, finally 17 factors were identified (Table 1).

To be quantitative and standard, the influence degree of the questionnaire is divided into five grades: critical, serious, moderate, minor and negligible. Then critical was given 5 points, serious 4 points, moderate 3 points, minor 2 points, and negligible 1 point. We have sent 20 questionnaires altogether, and 16 recycled, all recycle questionnaires were effective. The respondents include experts in Operational Department of Tencent (8), Ningo Students Studio (4) and the Department of Computer Science, Georgia Institute of Technology in USA (4).

Through the questionnaire analysis, the descriptive statistical analysis of each success factor was acquired (Table 2).

Ten factors with highest mean value were renumbered (Table 3). The top ten success factors of mobile Internet

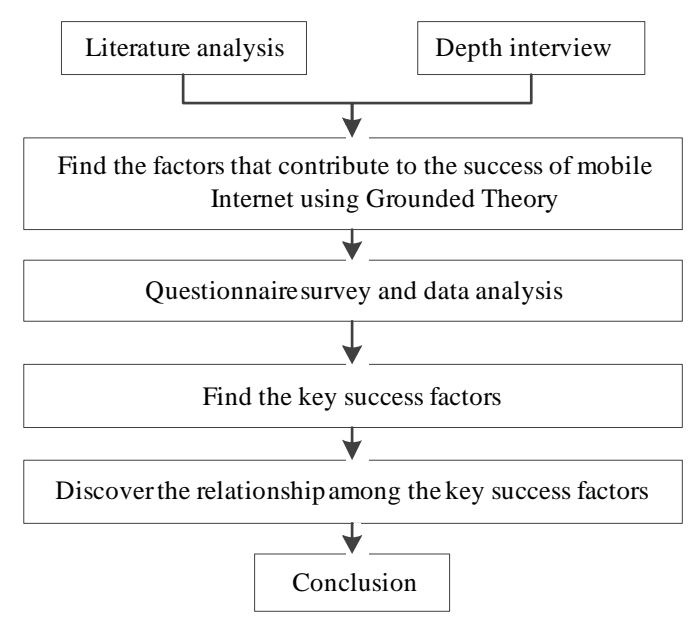

Figure 1. Research framework. 
Table 1. The influence factors of mobile internet.

\begin{tabular}{|c|c|}
\hline Factors & Introductions \\
\hline $\mathrm{F}_{1}$ User traffic and scale & Whether mobile Internet profit model can be formed or not is depend on the user scale and the business flow. \\
\hline $\mathrm{F}_{2}$ User consumption habit & $\begin{array}{l}\text { It is the key factors affecting the development of mobile Internet that cultivating the user consumption habit and using } \\
\text { habit. }\end{array}$ \\
\hline $\begin{array}{l}\mathrm{F}_{3} \text { Product and service } \\
\text { innovation }\end{array}$ & $\begin{array}{l}\text { The formation of good profit model of mobile Internet enterprises, in essence, depend on the whether it can provide the } \\
\text { attractive, innovative and differentiated product or service to the customer. }\end{array}$ \\
\hline $\begin{array}{l}\mathrm{F}_{4} \text { Keen market } \\
\text { environment sense }\end{array}$ & $\begin{array}{l}\text { In the open market of mobile Internet, the market environment changes rapidly and the competition is fierce. So the } \\
\text { keen grasp of the market environment is benefit for the enterprises to build the differentiated profit model, according to } \\
\text { their development status, the advantages and disadvantages. }\end{array}$ \\
\hline $\begin{array}{l}\mathrm{F}_{5} \text { Self-positioning of the } \\
\text { enterprise }\end{array}$ & $\begin{array}{l}\text { While mobile Internet is in its infancy in China and many enterprises are still busy accumulating customers at the cost } \\
\text { of loss. Therefore, to explore the sustainable mobile Internet profit model is very urgent, and it needs mobile Internet } \\
\text { enterprises to position themselves correctly. }\end{array}$ \\
\hline $\mathrm{F}_{6}$ User experience & $\begin{array}{l}\text { In order to promote the profit model innovation of and promote the prosperity of mobile Internet industry, the } \\
\text { enterprises need to be customer orientation, and focus on customer experience and business model innovation. }\end{array}$ \\
\hline $\begin{array}{l}\mathrm{F}_{7} \text { Innovation of business } \\
\text { model }\end{array}$ & $\begin{array}{l}\text { With the maturity of mobile Internet, all kinds of business model will appear. As to the current business model, the } \\
\text { development of mobile applications should be concentrated on. Business model is crucial for the sustainable } \\
\text { development and profitability of China's mobile Internet industry in the future. }\end{array}$ \\
\hline $\mathrm{F}_{8}$ Core technology & $\begin{array}{l}\text { As the leading force and driving force to the development of new media, technology is a basic question to mobile } \\
\text { Internet. Technology platform construction is the foundation of mobile Internet, relating to whether mobile Internet can } \\
\text { become the leading network. }\end{array}$ \\
\hline $\begin{array}{l}\mathrm{F}_{9} \text { Provide both free and } \\
\text { value added service }\end{array}$ & $\begin{array}{l}\text { Provides the basic services to the ordinary users for free, while offer value-added services to the VIP users with } \\
\text { differentiation demand. The former is more suitable for the current market environment to meet the basic needs, and the } \\
\text { latter can meet the differentiated demand of users. }\end{array}$ \\
\hline $\begin{array}{l}\mathrm{F}_{10} \text { High-tech technical } \\
\text { personnel }\end{array}$ & $\begin{array}{l}\text { High-tech technical personnel with strong receptivity and core technology play a important role in promoting the } \\
\text { development of the Internet. }\end{array}$ \\
\hline $\begin{array}{l}\mathrm{F}_{11} \text { Development of the } \\
\text { mobile terminal }\end{array}$ & $\begin{array}{l}\text { The advantage of mobile Internet lies in how to make the best use of the mobile terminal. Mobile terminals exist in } \\
\text { everywhere in one's life, as we have to use to mobile phone or tablet every day. }\end{array}$ \\
\hline $\mathrm{F}_{12}$ Network Development & $\begin{array}{l}\text { In terms of the network, because of the enhancement of the wireless data transmission capacity, the mobile extending } \\
\text { feasibility of the application within the group is enhanced greatly, which makes the wireless big data transmission, } \\
\text { multimedia transmission possible. }\end{array}$ \\
\hline $\begin{array}{l}\mathrm{F}_{13} \text { E-commerce and online } \\
\text { payment }\end{array}$ & $\begin{array}{l}\text { E-commerce is the trend of the future, and with the development of electronic commerce these years, the real economy } \\
\text { has been webified gradually. Mobile Internet era makes people's life become more convenient, and may even overturn } \\
\text { the lifestyle of society. }\end{array}$ \\
\hline $\begin{array}{l}\mathrm{F}_{14} \text { Business core } \\
\text { competitiveness }\end{array}$ & $\begin{array}{l}\text { To promote the profit model innovation in mobile Internet, it is necessary for the enterprise to position correctly, to } \\
\text { focus on customer experience and business model innovation in the business, and to insist on cooperation, building a } \\
\text { good industry ecosystem. }\end{array}$ \\
\hline $\mathrm{F}_{15}$ Customized service & $\begin{array}{l}\text { From the Internet's profit model, it is clearly that only the products and service most closely to the users can be } \\
\text { charged. }\end{array}$ \\
\hline $\begin{array}{l}\mathrm{F}_{16} \text { Available venture } \\
\text { capital }\end{array}$ & $\begin{array}{l}\text { Venture capital contributes to the development of high-tech industry, because it can reduce the risk in development of } \\
\text { mobile Internet enterprises. }\end{array}$ \\
\hline $\begin{array}{l}\mathrm{F}_{17} \text { Application of Cloud } \\
\text { computing and Big Data }\end{array}$ & $\begin{array}{l}\text { Cloud computing and the terminal will be the servers in the future, and mobile Internet enterprises can gradually } \\
\text { become a platform according to this strategy. }\end{array}$ \\
\hline
\end{tabular}

include: user traffic and scale, product and service innovation, keen market environment sense, user experience, business model innovation, core technology, development of mobile terminal, e-commerce and online payment services, customized services and application of Cloud and big data.

\section{The Relationship among the Key Success Factors}

ISM method was used to analyze the relationship among the top ten key success factors of mobile Internet. In order to express conveniently and uniformly, " $\mathrm{X}$ " in the 
Table 2. The descriptive statistical analysis of success factor of mobile internet.

\begin{tabular}{llcc}
\hline & Mean & Std. Deviation & Std. Error Mean \\
\hline $\mathrm{F}_{1}$ & 3.9528 & 0.56039 & 0.14010 \\
$\mathrm{~F}_{2}$ & 3.1787 & 0.65670 & 0.16418 \\
$\mathrm{~F}_{3}$ & 3.7111 & 0.71063 & 0.17766 \\
$\mathrm{~F}_{4}$ & 4.5434 & 0.68023 & 0.17058 \\
$\mathrm{~F}_{5}$ & 3.0139 & 0.42956 & 0.10739 \\
$\mathrm{~F}_{6}$ & 4.5673 & 0.50486 & 0.12622 \\
$\mathrm{~F}_{7}$ & 4.4321 & 0.79054 & 0.19763 \\
$\mathrm{~F}_{8}$ & 3.5434 & 0.70451 & 0.17613 \\
$\mathrm{~F}_{9}$ & 3.0022 & 0.40290 & 0.10073 \\
$\mathrm{~F}_{10}$ & 2.7673 & 0.68083 & 0.17021 \\
$\mathrm{~F}_{11}$ & 3.4853 & 0.60934 & 0.15234 \\
$\mathrm{~F}_{12}$ & 3.0906 & 0.54010 & 0.13503 \\
$\mathrm{~F}_{13}$ & 3.2487 & 0.75670 & 0.18918 \\
$\mathrm{~F}_{14}$ & 3.0544 & 0.57285 & 0.14321 \\
$\mathrm{~F}_{15}$ & 3.3067 & 0.62054 & 0.15514 \\
$\mathrm{~F}_{16}$ & 2.9133 & 0.43732 & 0.10933 \\
$\mathrm{~F}_{17}$ & 3.2015 & 0.64291 & 0.16073 \\
\hline
\end{tabular}

Note: sample size $\mathrm{N}=16$.

Table 3. Top10 key success factors of mobile internet.

\begin{tabular}{cl}
\hline Coding & \multicolumn{1}{c}{ Key success factors } \\
\hline $\mathrm{K}_{1}$ & User traffic and scale \\
$\mathrm{K}_{2}$ & Product and service innovation \\
$\mathrm{K}_{3}$ & Keen market environment sense \\
$\mathrm{K}_{4}$ & User experience \\
$\mathrm{K}_{5}$ & Business model innovation \\
$\mathrm{K}_{6}$ & Core technology \\
$\mathrm{K}_{7}$ & Development of mobile terminal \\
$\mathrm{K}_{8}$ & E-commerce and online payment services \\
$\mathrm{K}_{9}$ & Customized services \\
$\mathrm{K}_{10}$ & Application of Cloud and big data \\
\hline
\end{tabular}

cell was used to illustrate the row factor and the column factor influence each other, "V" means the row factor has influence to the column factor, while "A" has the opposite meaning, and the cell in space means there is no relationship between row factor and column factor (Table 4).

According to the results above, an adjacent matrix can be built. For the key success factor for mobile Internet $K_{i}(i=1,2, \cdots, 10)$, " 1 " means $K_{i}$ is influential to $K_{j}$, otherwise, " 0 " is used. So the relationship in Table 4 can be expressed as the adjacency matrix as follows:

$$
\begin{aligned}
& K_{1} K_{2} K_{3} K_{4} K_{5} K_{6} K_{7} K_{8} K_{9} K_{10} \\
& K_{1}\left(\begin{array}{llllllllll}
1 & 0 & 0 & 0 & 0 & 0 & 0 & 0 & 0 & 0
\end{array}\right) \\
& K_{2}\left(\begin{array}{llllllllll}
1 & 1 & 0 & 0 & 1 & 0 & 0 & 0 & 0 & 0
\end{array}\right. \\
& K_{3} \quad 0 \begin{array}{llllllllll} 
& 0 & 1 & 1 & 1 & 0 & 0 & 0 & 1 & 0
\end{array}
\end{aligned}
$$

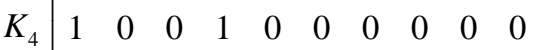

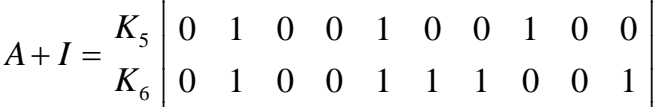

$$
\begin{aligned}
& K_{7} \mid \begin{array}{llllllllll}
0 & 0 & 0 & 0 & 0 & 0 & 1 & 1 & 0 & 0
\end{array}
\end{aligned}
$$

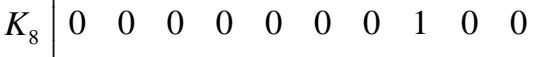

$$
\begin{aligned}
& K_{9} \mid \begin{array}{llllllllll}
0 & 0 & 0 & 1 & 0 & 0 & 0 & 0 & 1 & 0
\end{array} \\
& K_{10}\left(\begin{array}{llllllllll}
0 & 1 & 0 & 0 & 0 & 0 & 1 & 1 & 1 & 1
\end{array}\right)
\end{aligned}
$$

According to the formula:

$$
(A+I)^{k-1} \neq(A+I)^{k}=(A+I)^{k+1}=R
$$

(I refer to the unit matrix), the reachable matrix is acquired as follows with the ISM WIN 1.1 software:

$$
\begin{aligned}
& \begin{array}{llllllllll}
K_{1} & K_{2} & K_{3} & K_{4} & K_{5} & K_{6} & K_{7} & K_{8} & K_{9} & K_{10}
\end{array} \\
& K_{1}\left(\begin{array}{llllllllll}
1 & 0 & 0 & 0 & 0 & 0 & 0 & 0 & 0 & 0
\end{array}\right)
\end{aligned}
$$

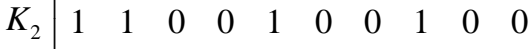

$$
\begin{aligned}
& K_{3} \quad 0 \begin{array}{llllllllll}
0 & 1 & 0 & 1 & 0 & 0 & 1 & 1 & 0
\end{array}
\end{aligned}
$$

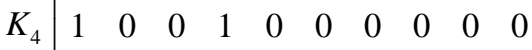

$$
\begin{aligned}
& R=\begin{array}{l|llllllllll}
K_{5} & 0 & 0 & 0 & 0 & 1 & 0 & 0 & 1 & 0 & 0 \\
K_{6} & 0 & 0 & 0 & 0 & 1 & 1 & 1 & 1 & 0 & 1
\end{array} \\
& K_{7} \mid \begin{array}{llllllllll}
0 & 0 & 0 & 0 & 0 & 0 & 1 & 1 & 0 & 0
\end{array} \\
& K_{8} \quad 0 \begin{array}{llllllllll}
0 & 0 & 0 & 0 & 0 & 0 & 1 & 0 & 0
\end{array} \\
& \begin{array}{l|llllllllll}
K_{9} & 0 & 0 & 0 & 0 & 0 & 0 & 0 & 0 & 1 & 0
\end{array} \\
& K_{10}\left(\begin{array}{llllllllll}
0 & 0 & 0 & 0 & 0 & 0 & 1 & 1 & 0 & 1
\end{array}\right)
\end{aligned}
$$

The set for each factor $K_{i}$ is obtained with the reachable matrix $R$ :

$$
\begin{gathered}
P\left(K_{i}\right)=\left\{K_{j} m_{i j}=1\right\} \\
Q\left(R_{i}\right)=\left\{K_{j} m_{j i}=1\right\} \\
P\left(K_{i}\right) \cap Q\left(K_{i}\right)=T\left(K_{i}\right)
\end{gathered}
$$

$P\left(K_{i}\right)$ is called to reachable set, namely the set of all the reachable factors from factor $K_{i} . Q\left(K_{i}\right)$, called advanced set, refers to the set of all the factors can reach $K_{i}$. $T\left(R_{i}\right)$ means the universal set, that is the set of all the factors both belong to the reachable set and the advanced set (Table 5).

The relationship description of the key success factors above are not intuitive enough. To express the relationship more clearly, the hierarchy is further analyzed (Table 6).

According to the hierarchy of the key success factors of mobile Internet, the ISM model of the key success factors of mobile Internet is set up (Figure 2). 
Table 4. The relationship among the key success factors of mobile internet.

\begin{tabular}{|c|c|c|c|c|c|c|c|c|c|c|c|}
\hline & & $K_{1}$ & & & & & & & & & \\
\hline$K_{1}$ & User traffic and scale & & $K_{2}$ & & & & & & & & \\
\hline$K_{2}$ & Product and service innovation & A & & $K_{3}$ & & & & & & & \\
\hline$K_{3}$ & Keen market environment sense & & A & & $K_{4}$ & & & & & & \\
\hline$K_{4}$ & User experience & A & $\mathrm{V}$ & & & $K_{5}$ & & & & & \\
\hline$K_{5}$ & Business model innovation & & $\mathrm{X}$ & $\mathrm{V}$ & & & $K_{6}$ & & & & \\
\hline$K_{6}$ & Core technology & & A & & & A & & $K_{7}$ & & & \\
\hline$K_{7}$ & Development of mobile terminal & & & & & & $\mathrm{V}$ & & $K_{8}$ & & \\
\hline$K_{8}$ & E-commerce and online payment services & & & & & $\mathrm{V}$ & & $\mathrm{V}$ & & $K_{9}$ & \\
\hline$K_{9}$ & Customized services & & & $\mathrm{V}$ & A & & & & & & $K_{10}$ \\
\hline$K_{10}$ & Application of cloud computing and big data & & A & & & & $\mathrm{V}$ & A & A & A & \\
\hline
\end{tabular}

Table 5. The reachable set, advanced set and universal set of the key success factors of mobile internet.

\begin{tabular}{cccc}
\hline $\boldsymbol{K}_{\boldsymbol{i}}$ & $\boldsymbol{P ( \boldsymbol { K } _ { \boldsymbol { i } } )}$ & $\boldsymbol{Q}\left(\boldsymbol{R}_{\boldsymbol{i}}\right)$ & $\boldsymbol{T}\left(\boldsymbol{R}_{\boldsymbol{i}}\right)$ \\
\hline$K_{1}$ & 1 & $1,2,4$ & 1 \\
$K_{2}$ & $1,2,5,8$ & 2 & 2 \\
$K_{3}$ & $3,5,8,9$ & 3 & 3 \\
$K_{4}$ & 1,4 & 4 & 4 \\
$K_{5}$ & 5,8 & $2,3,5,6$ & 5 \\
$K_{6}$ & $5,6,7,8,10$ & 6 & 6 \\
$K_{7}$ & 7,8 & $6,7,10$ & 7 \\
$K_{8}$ & 8 & $2,3,5,6,7,8,10$ & 8 \\
$K_{9}$ & 9 & 3,9 & 9 \\
$K_{10}$ & $7,8,10$ & 6,10 & 10 \\
\hline
\end{tabular}

Table 6. The hierarchy process of the key success factors of mobile internet.

\begin{tabular}{cccc}
\hline$K i$ & $P\left(K_{i}\right)$ & $Q\left(R_{i}\right)$ & $T\left(R_{i}\right)$ \\
\hline \multicolumn{5}{c}{ Stage $1=\left\{K_{2}, K_{3}, K_{4}, K_{6}\right\}$} \\
$K_{1}$ & 1 & 1 & 1 \\
$K_{5}$ & 5,8 & 5 & 5 \\
$K_{7}$ & 7,8 & 7,10 & 7 \\
$K_{8}$ & 8 & $5,7,8,10$ & 8 \\
$K_{9}$ & 9 & 9 & 9 \\
$K_{10}$ & $7,8,10$ & 10 & 10 \\
\multicolumn{5}{c}{ Stage $2=\left\{K_{1}, K_{5}, K_{9}, K_{10}\right\}$} \\
$K_{7}$ & 7,8 & 7 & 7 \\
$K_{8}$ & 8 & 7,8 & 8 \\
$K_{8}$ & \multicolumn{2}{c}{ Stage $3=\left\{K_{7}\right\}$} \\
\multicolumn{2}{c}{ Stage $4=\left\{K_{8}\right\}$} \\
\hline
\end{tabular}

The root key success factors affecting the development of mobile Internet are $K_{2}$ products and services innovation, $K_{3}$ keen market environment sense, $K_{4}$ user experience and $K_{6}$ core technology. They contribute to the middle layer of the interpretative structure model greatly.
For example, the keen market environment sense can promote the business model innovation, and the development of core technologies for plays a significant role in the application of cloud computing and big data, which then promotes the development of mobile Internet terminal greatly. Eventually, the root and intermediary factors directly affect the $K_{1}$ user traffic and scale, $K_{8}$ e-commerce and online payment and $K_{9}$ customized service. They are the surface key success factors and are relatively easy to be quantified, so they can be the intuitive measure of the development of mobile Internet. The enterprises of mobile Internet, mobile phone manufacturers and operators can evaluate their own development situation, according to quantifiable key success factors, and then guide and plan the development of themselves in the view of the root factors.

\section{Conclusion}

The top $10 \mathrm{KSF}$ of mobile Internet is found out with Grounded Theory: the user traffic and scale, product and service innovation, keen market environmental sense, user experience and business model innovation, core technology, the development of mobile terminals, ecommerce and online payment services, customized services and applications of cloud computing and big data. ISM is applied to analysis the root KSF affecting the development of mobile Internet, as they are product and service innovation, keen market environmental sense, user experience and core technology. The enterprises of mobile Internet, mobile phone manufacturers and operators can be enlightened from both the root success factors and their influence relation. In the future research, the results should be compared with other research results. And are there many differences between developed areas and undeveloped areas for the top $10 \mathrm{KSF}$ of mobile Internet? Are there many differences between China and USA for the top $10 \mathrm{KSF}$ of mobile Internet? Isn't it that the root KSF of the mobile Internet will change with 


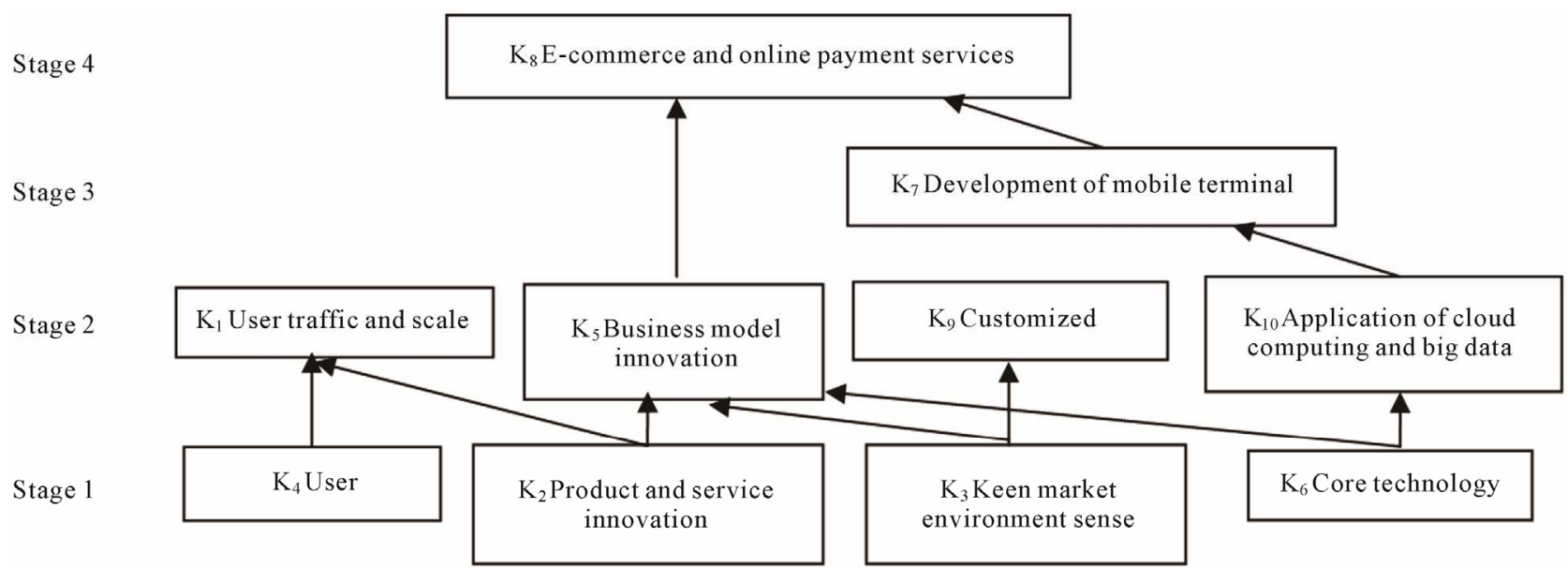

Figure 2. The hierarchical structure model of the key success factors of mobile internet.

time etc.?

\section{Acknowledgements}

Thanks for the helpful discussion with Mr. Decheng Dong, Mr. Daffy Yan, Mr. Haozhe Lee and Mr. Zirong Yan etc. Thanks the support to the questionnaire from Ningo Student Studio, Operational Department of Tencent.

\section{REFERENCES}

[1] M. Meeker, "Mary Meeker’s Latest Must-Read Presentation on the State of the Web," 2012.

http://www.businessinsider.com/mary-meeker-2012-inter net-trends-year-end-update-2012-12\#-1

[2] Y. F. Hu and S. L. Hu, "The Analysis of the Key Influence Factors of the Profit Model of Mobile Internet," Communications Management and Technology, Vol. 34, No. 6, 2012, pp. 39-41.
[3] K. Matsudaira, "Making the Mobile Web Faster," Communication of ACM, Vol. 56, No. 3, 2013, pp. 56-61. doi10.1145/2428556.2428572

[4] N. Jabeur, S. Zeadaly and B. Sayed, "Mobile Social Networking Applications," Communication of ACM, Vol. 56, No. 3, 2013, pp. 71-79. doi10.1145/2428556.2428573

[5] N. C. Zakas, "The Evolution of Web Development for Mobile Devices," Communication of ACM, Vol. 56, No. 4, 2013, pp. 42-48. doi10.1145/2436256.2436269

[6] I. Junglas and J. Harris, "The Promise of Consumer Technologies in Emerging Markets," Communication of ACM, Vol. 56, No. 5, 2013, pp. 84-90. doi10.1145/2447976.2447995

[7] C J. orbin and A. Strauss, “A Basics of Qualitative Research: Techniques and Procedures for Developing Grounded Theory,” Sage, London, 1990.

[8] J. N. Warfield, "The Mathematics of Structure," AJAR, Publishing Company, Palm Harbor, 2003. 